\title{
Applicative Economic Geography in General Grammar School in Slovenia
}

\author{
Eva Konečnik Kotnik
}

Within the contribution "Applicative Economic Geography in General Grammar School in Slovenia", the selection of learning objectives in the syllabus for geography in general grammar school in Slovenia are presented. The selection of objectives relates to economic geography. This article presents the results of generic comparative analysis of learning objectives within the framework of the quoted substantive area of syllabi, which have been issued during the period from the emergence of Slovenia as an independent state (1992, 1998 and 2008).

We present here the results of the evaluation of quoted learning objectives from the viewpoint of social needs and, respectively, the applicability of the quoted learning objectives, as well as the results of the evaluation of current learning objectives from the viewpoint of teaching practice in the general grammar school on the part of teachers of geography in the general grammar schools.

Key words: applicative economic geography, grammar schools, Slovenia

\section{Primijenjena ekonomska geografija u slovenskim gimnazijama}

U okviru priloga „Primijenjena ekonomska geografija u slovenskim gimnazijama”, predstavljen je odabir ciljeva učenja u nastavnom programu za geografiju u slovenskim gimnazijama. Odabir ciljeva odnosi se na ekonomsku geografiju. Ovaj članak predstavlja rezultate generičke komparativne analize ciljeva učenja u okviru navedenog područja nastavnih programa izdanih u periodu od slovenske neovisnosti (1992., 1998. i 2008).

U članku se sagledavaju rezultati navedenih ciljeva učenja s gledišta društvenih potreba odnosno njihova primjenjivost. Također, sagledavaju se i rezultati evaluacije trenutnih ciljeva učenja s gledišta nastavničke prakse profesora geografije u gimnazijama.

Ključne riječi: primijenjena ekonomska geografija, gimnazije, Slovenija 


\section{INTRODUCTION}

The United Nations have proclaimed the years 2005 to 2014 as the Decade of Education for Sustainable Development. In 2005, the Strategy for Education for Sustainable Development was adopted at the High-level Meeting of Education and Environment Ministries in Vilnius, also giving priority to education for sustainable development. The main idea of the adopted document was to encourage the development of new educational methods for approaching the problems of sustainable development, as well as to finding solutions. The need to depart from traditional approaches was particularly emphasised, as well as from connecting sustainable development with environmental education that was too narrow content-wise (Uzelac 2008; qtd. in Kolenc Kolnik 2007, 22).

Most countries incorporating the requirements for sustainable development into their development strategies take the following five dimensions of sustainable development into account:

- global responsibility;

- intergenerational equity;

- integration of economic, social and environmental objectives;

- the principle of developmental caution; and,

- the principle of co-operation with the public and its integration in decision-making (Kolenc Kolnik 2007, 22).

\section{Objectives and Methodology of the Study}

Among the above-listed five dimensions of sustainable development, we have focused in this paper on the integration of economic, social and environmental objectives of economic geography in general grammar schools in Slovenia. Besides that, we have researched the idea of sustainable development in the selected syllabi. In Slovenia, general grammar schools are secondary schools providing general education and preparing students aged from 15 to 19 years for further education at university. Because an increasing portion of the primary school population is enrolled later in general grammar schools, these represent an important part of Slovenia's education system. Educational impulses in general grammar schools are the basis for lifelong learning, especially since the enrolled population is capable of the highest cognitive processes, and because the population will attend universities, thus decisively affecting the future quality of life, as well as the sustainable development of the Earth.

The basic research process involved a comparative analysis of the basic documents for geography education in Slovenian general grammar schools. Three syllabi from the period after Slovenia declared its independence were used: from the years 1992, 1998 and 2008. Analysing each syllabus, we tried to answer the following questions:

- Is the idea of sustainable development incorporated, and, if so, in what way?

- Is the integration of economic, social and environmental objectives present? How is the integration realised? Could it have been realised better? 
As far as structure is concerned, all studied Slovenian geography syllabi for general grammar schools consist of the following four basic sets of lesson objectives: general geography, regional geography of the World, regional geography of Europe and regional geography of Slovenia. General geography is concerned with the thematic units of physical geography and social geography, which are subdivided into the following chapters: Origin and Structure of the Earth, Earth's Surface, Weather and Climate, Soil, Vegetation, Hydrosphere, Population, Settlements, Human Economic Activity. Regional geography is concerned with regio-geographical aspects (physical and social geography of a particular region). In the study we focused on general geography, which, because of its thematic orientation, meets the demands of spatial integration, which is one of the most important criteria in education for sustainable development (in the objectives of regional geography, spatial integration is limited to an occasional comparison between different regions).

In the comparative analysis of the syllabi, the following structural elements of the Slovenian geography syllabi were taken into account: general objectives and operational objectives.

Additionally, the data used in the study was collected with the help of evaluation questionnaires (protocols), which were filled out by university geography teachers $(78.5 \%$ of the selected university teachers took part), geography teachers in Slovenian general grammar schools (37.5\% of the population took part) and half (14) of the students of the Faculty of Arts in Maribor, who were in the fourth year of their studies in 2008 (when the research was conducted), and were familiar with the grammar school syllabus in some detail.

A quantitative and qualitative analysis followed on the basis of the evaluation questionnaires (protocols). Within the framework of the quantitative analysis, the data was statistically processed using the SPSS statistical software package for Windows (Version 15.0). The nonparametric Kruskal-Wallis test was used for determining the differences between groups of teachers concerning their period of employment and level of education. The qualitative processing was done by closely examining and summing up the evaluation protocols (questionnaires). Common characteristics were especially emphasised and abstracted.

\section{RESULTS OF THE STUDY}

\section{Inclusion of the Idea of Sustainable Development in the Syllabi}

In many instances, the general geography learning objectives in the studied documents clearly relate to the idea of sustainable development. $50 \%$ of the learning objectives in the 1992 and 1998 syllabi include the idea of sustainable development, although the term itself is not mentioned directly.

An example of a general objective from 1992 (138): "become aware of the consequences of unplanned management of natural resources, and are thus trained to make conscious decisions regarding activities affecting the environment, which will not disrupt the natural balance and will not damage the environment (ecological aspect in spatial decision making)". 
An example of a general objective from 1998 (4): "develop the ability to evaluate the environmental contradictions in the modern world stemming from population development and economic development; because of disregard for the spatial limitations of human activity".

The absolute number of general objectives supporting the idea of sustainable development is higher in the 1998 syllabus. The 2008 syllabus differs substantially from preceding syllabi in the way the general objectives are formulated. On approximately three pages, the general learning objectives are defined. They are then divided into cognitive objectives; objectives related to spatial understanding; objectives related to the knowledge and understanding of geographical structures, processes and relationships; objectives related to the application of knowledge and skills; educational objectives (in total, there are 57 general objectives, which is approximately five times as many as in the preceding two syllabi). In addition to the aforementioned general objectives, the 2008 syllabus also contains eleven groups of important inter-subject competences, which can be developed in the geography lessons. Approximately 75 competences are defined. All of the above serves the purpose of strengthening the inter-disciplinary quality, which is important for the understanding and realisation of sustainable development. Objectives supporting the idea of sustainable development are present in each group of general objectives and particularly in the group of educational objectives.

\section{Examples of general objectives in the syllabus $(2008,11)$ :}

"are raised to be interested in societal needs; in solving general spatial (sustainable) problems on a national, a wider regional and the global level";

"adopt a concern for a balanced spatial use and for the preservation of the natural and social environment for future generations (sustainable development)";

"are raised to understand the importance of values when making decisions about activities affecting the physical space";

"develop awareness about solving local, regional and global problems in accordance with the principles of sustainable development, as well as the principles of the Universal Declaration of Human Rights".

The term "sustainable development" is directly included in the general objectives of the 2008 geography syllabus for Slovenian general grammar schools. This idea is thus incorporated in the system of geography education.

\section{Integration of Economic, Social and Environmental Objectives in the Syllabi}

Only the content is defined in the 1992 syllabus, whereas the operational objectives are not. The direction towards sustainable development is evident in $70 \%$ of the chapters concerned with general geography. The cognitive comprehension of the effects of human activity on nature is the primary objective. In the 1998 syllabus, the (operational) learning objectives are defined in detail. A detailed analysis of the operational learning objectives in general geography showed that the share of learning objectives related to raising environmental awareness and co-responsibility in environmental protection (educational cross-curricular component) is $46.6 \%$. These objectives are most common in physical 
geography, followed by social geography; especially in the chapter entitled "Human Economic Activity". The share of learning objectives addressing the understanding of spatial problems and directing towards a responsible development of the economy and society is $58.5 \%$.

In the 2008 syllabus, the share of "environmental" objectives in general geography rose especially in the chapters entitled "Weather and Climate" and "Human Economic Activity". In the latter chapter, the largest share of "environmental" objectives is found in the thematic sets entitled "Energy and Industry" and "Agriculture", whereas the thematic set entitled "Sustainable Development" is completely new in comparison to the preceding syllabi.

In the chapter entitled "Agriculture" (2008, 24), the students become familiar with different types of agriculture and the causes for their origin, evaluate the use of soil, using select examples, and learn which elements of the landscape are functionally related to agriculture. They also "try to determine which environmental problems arise from intensive agriculture, as well as which environmental problems related to the irresponsible management of nature affect nature the most", and "develop a positive relationship towards the importance of agriculture for food supply, the supply of raw materials and the preservation of the cultural landscape". On the example of agriculture, the difference between the two newest syllabi is that the 2008 syllabus more clearly puts emphasis on educational factors, as well as on the importance of the development of knowledge and talents.

In the thematic set entitled "Sustainable Development" (2008, 25-26), which is clearly application-orientated, the main emphasis is put on learning about the concept and the essence of sustainable development and its components, on understanding the importance and the issues of spatial planning, the inclusion of the public in the decision-making process, the assessment of different activities from the perspective of sustainable development and the awareness of the complexity and limitations of space, as well as on the assessment of development processes and the spatial development of economic activities.

We can conclude that the 1992 and 1998 syllabi represent a content-wise narrower environmental education, whereas the new syllabus represents education for sustainable development.

Although there are relatively many objectives in general geography in the 1998 and 2008 syllabi that can be connected to the idea of sustainable development, the chapter entitled "Human Economic Activity" shows that the approach towards economic activities is still very much systematic and descriptive (learning about different economic activities separately). This places doubt on the actual effectiveness of the integration of economic, social and environmental objectives.

\section{New Syllabus Simulations - a Step towards the Integration of Economic, Social and Environmental Objectives?}

In order to make a step forward towards the integration of economic, social and environmental objectives, two additional simulations were prepared on the example of the chapter entitled "Human Economic Activity". In the simulation, the results of the 
assessment of the 1998 syllabus were taken into consideration. The societal needs, educational guidelines and geographical science were considered (Konečnik Kotnik 2008).

\section{Simulation Description}

The transition in the first simulation is slower; representing an evolutionary step towards modern processive understanding of economic geography, whereas the second simulation represents a more significant (revolutionary) content-related leap forward. In addition to the description of select economic activities included in the 1998 and 2008 syllabi, the first syllabus simulation also includes some tertiary and quaternary activities not included in the aforementioned syllabi; despite their importance in the economically developed world. Most objectives of the first simulation are directed towards the development of psychomotor skills and talents of the students, and their personal assessment of economic problems and stance on these problems, thus combining different aspects of education. The biggest difference regarding content lies in the fact that, in addition to human economic activity, the first simulation also includes economic processes (tertiarisation of the economy, economic globalisation, economic integration, spatial planning, indicators of sustainable development, etc.). The reason for including these objectives is the need for procedural emphasis; not only methodical, but also content-related.

The main difference between the first and the second syllabus simulation is the fact that individual economic activities are not described (not addressed) in the second one. Instead, this aspect is limited to the crucial indicators of economic development, social development and environmental development. These indicators are also compared on the basis of more developed and less developed or undeveloped regions of the World. This represents a completely different content-related approach. Content-wise, the approach of the second simulation was a distinctly complex and processive one, relevant from the viewpoint of modern economic geography, as well as from the viewpoint of raising awareness of the importance of the sustainable development of the Earth.

Some examples of learning objectives from the second syllabus simulation

Students:

- define key indicators of economic development;

- determine the key indicators of economic development of the selected developed and underdeveloped regions (by comparing the relevant data); with special focus on Slovenia;

- establish the factors that influenced the development of the most important economic activities, and assess the importance of these factors today and in the past; using developed and underdeveloped regions of Slovenia as concrete examples;

- determine the key indicators of social development of the selected developed and underdeveloped regions (by comparing the relevant data); with special focus on Slovenia;

- compare the key indicators of economic and social development; with the help of concrete regional examples;

- determine the key indicators of environmental development of the selected developed and underdeveloped regions (by comparing the relevant data); with special focus on Slovenia; 
- compare the key economic, social and environmental indicators; with the help of concrete examples;

- assess, with the help of examples, how their own values can have an impact on the economic, social, environmental and political problems of the local and global regions.

Source: Konečnik Kotnik 2008

\section{Key Findings}

In our study, the 1998 and 2008 syllabi and the described simulations were assessed by their direct users who are carrying out the teaching process: grammar school teachers and geography students. We wanted to determine how big a "leap" the teachers and students are willing to make in their teaching or how they assess the different principles of the integration of economic, social and economic objectives. The participants assessed the syllabi and the simulations using the following criteria:

Tab. 1 Criteria for syllabus assessment from the viewpoint of the direct users of the syllabus

Tab. 1. Kriteriji procjene nastavnog programa s gledišta direktnih korisnika nastavnog programa

\begin{tabular}{|l|l|}
\hline 1st criterion: & $\begin{array}{l}\text { The proportion between cognitive objectives ("material" knowledge), } \\
\text { psychomotor objectives (skills, talents) and educational objectives. }\end{array}$ \\
\hline 2nd criterion: & Accordance with life and societal needs. \\
\hline 3rd criterion: & Applicability of the knowledge. \\
\hline 4th criterion: & Relevance of the content and the concepts. \\
\hline 5th criterion: & The possibility of content actualisation. \\
\hline 6th criterion: & Accordance with geographical science. \\
\hline 7th criterion: & $\begin{array}{l}\text { Concept of the approach (methodological approach to forming the } \\
\text { syllabus for each chapter). }\end{array}$ \\
\hline 8th criterion: & International comparability of the syllabus. \\
\hline 9th criterion: & $\begin{array}{l}\text { The burden on the teacher (difficulties in planning and carrying out } \\
\text { the lessons). }\end{array}$ \\
\hline 10th criterion: & The level of freedom and creativity that the syllabus allows the teacher. \\
\hline 11th criterion: & The level of assistance the syllabus offers the teacher. \\
\hline 12th criterion: & The burden on the students. \\
\hline 13th criterion: & Student motivation. \\
\hline 14th criterion: & $\begin{array}{l}\text { Suitability of the scope of the chapter considering its educational } \\
\text { potential. }\end{array}$ \\
\hline 15th criterion: & Syllabus support by textbook material, literature and sources. \\
\hline
\end{tabular}

Source: Konečnik Kotnik 2008 
We have established that practising teachers in Slovenian general grammar schools prefer gradual changes, since they evaluated the second (most "revolutionary") syllabus simulation as the least appropriate. On the other hand, this simulation was evaluated as the best one by university teachers; since it was also developed on the basis of their ideas. We can presume that practising teachers in Slovenian general grammar schools regard describing (of economic activities - e.g. which types of agriculture exist) and understanding of (economic) processes as equally important parts of geography education. Finding the right balance between these two aspects of geography education can prove very difficult. There is a risk of the quantity of the information becoming more important than the quality. Assessors with a higher level of education and geography students were more in favour of more drastic syllabus changes. Teachers with a shorter period of employment were also more in favour of syllabus changes. An interesting difference was also found in the ascribing of importance to different criteria. For practising teachers the most important criteria were "the teacher's burden", "the level of assistance the syllabus offers the teacher" and "support by textbook material, literature and sources". This suggests that the basis of their thinking is their own work. For student assessors the most important criteria in evaluating syllabuses were "the level of creativity the syllabus allows the teacher", "accordance with geographical science" and "international comparability". It is evident that they strive for a more liberal syllabus, which is open to scientific research, as well as to international developments.

\section{CONCLUSION}

The results of the study prove that the idea of sustainable development is firmly grounded in the Slovenian geography syllabus for general grammar schools. Nevertheless, certain dilemmas persist in this field. The first relates to the fact that the general objectives of geography education in the syllabus are well-formulated; they pay regard to basic social and educational requirements of modern times and not least to the trends in geographical science. This is true for the 2008 syllabus, as well as (to a lesser extent) for the 1998 syllabus. Problems arise when it comes to the realisation of the general objectives in the framework of the operational objectives, since the teachers have to deal with these directly. Examining the 1998 syllabus, it is evident that only $23 \%$ of the operational objectives were of educational - upbringing nature, $30 \%$ of the operational objectives were related to the development of skills and talents, and $26.3 \%$ were cross-curricular operational objectives. The idea of interconnecting different educational aspects is one of the foundations of the education for sustainable development, and was well-formulated in the general objectives. Nevertheless, it was not reflected adequately in the operational objectives. The question of the realisation of the general objectives and competences in the 2008 syllabus remains open to research. In the future, more emphasis is going to have to be put on the proportion between the general and operational objectives. In this respect, encouraging the continuing professional education of teachers is also of great importance.

This study established that there are other possibilities for (greater) integration of economic, social and environmental objectives. Considering that educational practice adapts to evolutionary changes more easily, gradual and planned syllabus development in the direction of greater integration of the aforementioned groups of objectives is necessary. 


\section{REFERENCES}

Konečnik Kotnik, E., 2008: Vrednotenje učnega načrta za geografijo v splošni gimnaziji v Sloveniji z vidikov družbenih potreb, izobraževalnih smernic in geografske znanosti; doktorska disertacija, Univerza v Mariboru, Filozofska fakulteta.

Kolenc Kolnik, K., 2007: Proaktivnost in terensko delo v izobraževanju za trajnostni razvoj; Revija za geografijo 4 (2-2), 21-28, Univerza v Mariboru, Filozofska fakulteta.

Uzelac, V., 2008: Teorijsko-praktični okvir cjeloživotnog učenja za održivi razvoj, in: Cjeloživotnoučenje za održivi razvoj (Uzelac, V., Vujičić, L., ur.). Učiteljski fakultet Sveučilišta Rijeka, Svezak 1, 27-54.

\section{SOURCES}

Gimnazijski program, 1992: Ljubljana, Zavod za šolstvo.

Učni načrt - predmetni katalog, Geografija, Splošna gimnazija, 1998: http://portal.mss.edus.si/msswww/programi, (4.5.2006)

Učni načrt, Geografija, Splošna gimnazija, 2008: http://portal.mss.edus.si/msswww/programi (11.11.2010)

Received (Primljeno): 2010 - 12 - 27

Accepted (Prihvaćeno): $2011-03-17$

Eva Konečnik Kotnik, Ph.D.,

Assistant for Didactics of Geography and Social Geography

Didactics of Geography, Social Geography University of Maribor, Faculty of Arts, Koroška cesta 160,2000 Maribor, Slovenia eva.konecnik@uni-mb.si 
